\title{
The ECJ and the ECtHR: The Future Relationship between the Two European Courts
}

\author{
Tobias Lock \\ DAAD/Clifford Chance Lecturer, Faculty of Laws, University College London, UK
}

\begin{abstract}
The current relationship between the two European courts has been discussed in some great detail while the future of that relationship has been widely neglected. This is somewhat surprising as the entry into force of the Lisbon Treaty and with it of the EU Charter of Fundamental Rights as well as the EU's succession to the ECHR are probably going to take place before too long. The article first examines Article 52(3) of the Charter, which prescribes that the ECHR be the minimum standard of human rights in the EU. It is argued that Article 52 (3) does not entail a reference to the ECtHR's case law so that the ECJ will not be bound by that case law. After an accession of the EU to the ECHR, it is likely that both courts will assert that they have exclusive jurisdiction over the ECHR in inter-state cases, which creates a jurisdictional conflict for which a solution must be found. In addition, the article explores whether after an accession, the Bosphorus case law will have a future and whether the dictum found in Opinion 1/91 will be applicable, according to which the ECJ is bound by the decisions of courts created by an international agreement to which the EC is a party.
\end{abstract}

\section{Keywords}

ECJ; ECtHR; EU Charter of Fundamental Rights; ECHR accession; Bosphorus case; exclusive jurisdiction; jurisdictional conflict

\section{Introduction}

In recent years, the legal relationship between different international courts has attracted more and more scholarly attention. The so-called proliferation of international courts and tribunals has led to a debate about potential jurisdictional overlaps or even conflicts between these courts. ${ }^{1}$ The

\footnotetext{
1) On this discussion see for instance: Tullio Treves, "Conflicts Between the International Tribunal for the Law of the Sea and the International Court of Justice", 31 New York University Journal of International Law \& Politics (1999) 809; Hugh Thirlway, "The Proliferation of International Judicial Organs and the Formation of International Law" in W.P. Heere (ed.), International Law
} 
present article will focus on the future relationship between two of the busiest international courts in the world: the Court of Justice of the European Communities (ECJ) and the European Court of Human Rights (ECtHR). In a preliminary step, the well-known present relationship between these two courts will be briefly examined. On that basis their future relationship will be explored. The two courts' relationship is likely to change in two scenarios: first, once the EU Charter of Fundamental Rights has entered into force and second, after an accession of the European Communities to the European Convention on Human Rights (ECHR).

\section{Present Situation}

Presently, the European Community is not a party to the ECHR and therefore not directly bound by it. ${ }^{2}$ According to the well-established case law of the ECJ, which is reflected in Article 6 (2) EU, the ECHR constitutes the minimum standard for human rights in the EU because all EU Member States are also bound by the ECHR. ${ }^{3}$ However, this does not imply that the EC itself is bound by the ECHR. As long as the EC itself is not a member to the Convention, the Convention rights have only got an indirect influence on the scope of fundamental rights in the European

and The Hague's 750th Anniversary (Springer, The Hague 1999), 433; Shane Spelliscy, "The Proliferation of International Tribunals: A Chink in the Armor", 40 Columbia Journal of Transnational Law (2001) 143; Gilbert Guillaume, "The proliferation of international judicial bodies: The outlook for the international legal order", Speech to the Sixth Committee of the General Assembly of the United Nations of 27 October $2000<$ http://www.icj-cij.org/court/index.php? pr=85\&pt=3\&p1=1\&p2=3\&p3=1>, 23 April 2009; Jean-Marie Dupuy, "The Danger of Fragmentation or Unification of the International Legal System and the International Court of Justice”, 31 New York University Journal of International Law \& Politics (1999) 791; Yuval Shany, The Competing Jurisdictions Between International Courts and Tribunals (OUP, Oxford 2004), pp. 1-11.

2) The EC is presently not competent to accede to the ECHR: Opinion 2/94 Accession to the $E C H R$ [1996] ECR I-1759; analyses of that opinion can be found in: Panos Koutrakos, EU International Relations Law (Hart, Oxford 2006), pp. 128-132; Piet Eeckhout, External Relations of the European Community (OUP, Oxford 2004), pp. 82-87; Anthony Arnull, "Left To Its Own Devices? Opinion 2/94 and the Protection of Fundamental Rights in the European Union" in A. Dashwood and C. Hillion (eds.), The General Law of E.C. External Relations (Sweet \& Maxwell, London 2000), p. 774; Matthias Ruffert, Europäische Grundrechte Zeitschrift [1996] 197. In addition, the ECHR is presently only open to states.

3) Paul Craig and Grainne de Búrca, EU Law (4th edn., OUP, Oxford, 2007), pp. 385-386; Christoph Grabenwarter, Europäische Menschenrechtskonvention (3rd edn., C.H. Beck, München 2008), 27. 
Community so that the Community itself cannot be held responsible for possible infringements of these rights. ${ }^{4}$ The Member States, however, are bound by both: Community law and the ECHR. This means that when implementing Community law, the Member States must generally comply with the ECHR.

On various occasions both the European Commission of Human Rights (ECommHR $)^{5}$ and the ECtHR had to decide cases directed against Member States of the EC, concerning actions by Member States that had been determined by Community law. ${ }^{6}$ The two most important decisions for the present relationship between Community law and the ECHR are the cases of Matthews and Bosphorus. According to the ECtHR's decision in Matthews, Member States are responsible if EC primary law (in that case the EC Act on Direct Elections of 1976) violates the Convention. ${ }^{7}$ The main reasons for this are that although the Member States are not excluded from transferring competences on an international organization, they remain responsible for infringements of the ECHR after such a transfer. ${ }^{8}$ Moreover, the respondent United Kingdom had freely agreed to be bound by the act in question and EC primary law cannot be challenged before the ECJ. ${ }^{9}$

In the more recent Bosphorus decision, the ECtHR was faced with the question of whether an EU Member State, in this case Ireland, could be held responsible under the Convention for the mere execution of an EC Regulation. ${ }^{10}$ The ECtHR had to reconcile two basic principles: On the

4) CFTD v European Communities, (App no 8030/77) (1978) D.R. 13, 213; Dufay v European Communities, (App no 13539/88) (ECommHR 19 Jan 1989).

5) The ECommHR was abolished by the 11 th protocol to the ECHR, which entered into force on 1 Nov 1998.

6) $M$ \& Co. $v$ Germany (App no 13258/87) (1990) D.R. 64, 146; Procola v Luxembourg (App no 14570/89) (1993) D.R. 75, 5; Cantoni v France (App no 17862/91) (1996) ECHR 1996-V; Senator Lines $v 15$ Member States of the EC (App no 56672/00) (2004) ECHR 2004-IV; Emesa Sugar $v$ Netherlands (App no 62023/00) (ECHR 13 Jan 2005).

7) Matthews $v$ United Kingdom (App no 24833/94) (1999) ECHR 1999-I. Cf. case-notes by: Iris Canor, "Primus inter pares. Who is the ultimate guardian of fundamental rights in Europe?", 25 European Law Review (2000), 3; Toby King, "Ensuring human rights review of intergovernmental acts in Europe", 25 European Law Review (2000), 79; Sebastian Winkler, "Der Europäische Gerichtshof für Menschenrechte, das Europäische Parlament und der Schutz der Konventionsgrundrechte im Europäischen Gemeinschaftsrecht”, Europäische Grundrechte Zeitschrift [2001] 18.

8) Matthews (n 7) para. 32.

9) Matthews (n 7) para. 33.

10) Bosphorus v Ireland (App no 45036/98) 2005 ECHR 2005-VI; confirmed by Coopérative des 
one hand, parties to the Convention are not prevented from transferring powers to an international organization. On the other hand, a party cannot fully escape its responsibilities under the Convention by such a transfer. According to the ECtHR, a Member State remains responsible under Article 1 ECHR for all acts and omissions of its organs regardless of whether they are rooted in domestic law only or are a consequence of the State's membership in the EC. ${ }^{11}$ An action taken in compliance with obligations arising from the membership in an international organization, however, can be justified as long as that organization protects human rights at least in a manner equivalent to that of the Convention, if the Member State has no discretion in implementing these obligations. ${ }^{12}$ Equivalent, according to the ECtHR, means comparable and not identical. If such equivalent protection is found to exist, there will be a presumption that a State has not departed from the requirements of the Convention when it does no more than implement the obligations flowing from its membership in the organization. ${ }^{13}$ The presumption, however, is rebutted when the protection offered was 'manifestly deficient', which would have to be examined on a case by case basis. The ECtHR went on to conclude that the European Community did in fact afford such a level of protection and that the presumption in that case was not rebutted. ${ }^{14}$ Therefore, the complaint

agriculteurs de mayenne v France (App no 16931/04) (2006); cf. case notes on Bosphorus by: Sionaidh Douglas-Scott, "A Tale of Two Courts: Luxembourg, Strasbourg and the Growing European Human Rights Acquis", 43 Common Market Law Review (2006) 243; Alicia Hinarejos Parga, "Bosphorus v Ireland and the Protection of Fundamental Rights in Europe", 31 European Law Review (2006), 250; Cathryn Costello, "The Bosphorus Ruling of the European Court of Human Rights: Fundamental Rights and Blurred Boundaries in Europe", 6 Human Rights Law Review (2006) 87; Jean Paul Jacqué, 41 Revue Trimestrielle de Droit Européen (2005) 749; Sebastian Winkler, "Die Vermutung des 'äquivalenten Grundrechtsschutzes' im Gemeinschaftsrecht nach dem Bosphorus-Urteil des EGMR", Europäische Grundrechte Zeitschrift [2007] 641; Jürgen Bröhmer, "Die Bosphorus-Entscheidung des Europäischen Gerichtshofs für Menschenrechte Der Schutz der Grund - und Menschenrechte in der EU und das Verhältnis zur EMRK", Europäische Zeitung für Wirtschaftsrecht (2006) 71; Stefan Lorenzmeier, "Das Verhältnis von europäischem Gemeinschaftsrecht und Europäischer Menschenrechtskonvention”, Jura [2007] 370; Gerrit Schohe, "Das Urteil Bosphorus: zum Unbehagen gegenüber dem Grundrechtsschutz durch die Gemeinschaft", Europäische Zeitung für Wirtschaftsrecht [2006] p. 33; Nikolaos Lavranos, "Das So-Lange-Prinzip im Verhältnis von EGMR und EuGH", Europarecht [2006)]79.

11) Bosphorus (n 10) paras. 152-153.

12) Bosphorus (n 10) para. 155.

13) Bosphorus (n 10) para. 156.

14) Bosphorus (n 10) paras. 159-166. The Bosphorus decision is reminiscent of the ECommHR's decision in $M$ \& Co. $v$ Germany (App no 13258/87) (1990) D.R. 64, 146 where the ECommHR 
was held to be unfounded. The ECtHR also made it clear that the presumption in Bosphorus only operates where the Community law at issue could be challenged before the ECJ. Therefore it does not apply where, as was the case in Matthews, the compliance of primary law with the ECHR is at issue.

The Bosphorus decision further clarifies that the presumption only applies where the Member State had no discretion in implementing Community law. ${ }^{15}$ Where the Member State had some degree of discretion, its responsibility will be the same as if a purely domestic act had been at issue. ${ }^{16}$ One of the questions left open by the ECtHR is whether the presumption also applies in cases where there has been no national act executing Community law. Such a case could for instance arise where an applicant directly challenges a decision rendered by the Commission and confirmed by the ECJ before the ECtHR. Bosphorus is based on the presumption that the protection of human rights in Community law is equivalent to that under the Convention. Therefore, the ECtHR presumes that in cases where the Community's Member States had no discretion when implementing secondary Community legislation that the Member States complied with the requirements of the Convention. Therefore, Bosphorus privileges secondary Community law as such. Thus the presumption formulated by the ECtHR in Bosphorus must also be applicable in cases where there was no implementing action by Member States. ${ }^{17}$

\footnotetext{
held that such complaints were inadmissible. A similar line of reasoning, albeit different in detail, can be found in the Solange II-decision by the German Federal Constitutional Court; cf. Alicia Hinarejos Parga, "Bosphorus v Ireland and the Protection of Fundamental Rights in Europe", 31 European Law Review (2006), 250, 257-258; Cathryn Costello, "The Bosphorus Ruling of the European Court of Human Rights: Fundamental Rights and Blurred Boundaries in Europe", 6 Human Rights Law Review (2006) 87, 104-105; Jean-Paul Jacqué, 41 Revue Trimestrielle de Droit Européen (2005), 749, 763; Stefan Lorenzmeier, "Das Verhältnis von europäischem Gemeinschaftsrecht und Europäischer Menschenrechtskonvention", Jura [2007] 370, 373; Gerrit Schohe, "Das Urteil Bosphorus: zum Unbehagen gegenüber dem Grundrechtsschutz durch die Gemeinschaft", Europäische Zeitschrift für Wirtschaftsrecht [2006], 33; Nikolaos Lavranos, "Das So-Lange-Prinzip im Verhältnis von EGMR und EuGH", Europarecht [2006], 79, 86.

15) The ECtHR therefore did not deviate from its previous Cantoni decision, Cantoni v France (App no 17862/91) ECHR 1996-V, where it held France responsible for the implementation of an EC directive.

16) Jean-Paul Jacqué, 41 Revue Trimestrielle de Droit Européen (2005), 749, 766; Alicia Hinarejos Parga, "Bosphorus v Ireland and the Protection of Fundamental Rights in Europe", 31 European Law Review (2006) 250, 257.

17) This view is shared by: Nikolaus Marsch and Anna-Catharina Sanders, "Gibt es ein Recht der
} 
While the general tenor of the ECtHR's case law is that Member States cannot escape their obligations under the Convention, the Bosphorus decision must be regarded as proof of the continued silent cooperation and mutual respect between the ECtHR and the ECJ. The ECJ regularly refers to the ECHR and the ECtHR's case law when adjudicating on fundamental rights in Community law, for which one of the main sources of inspiration is the ECHR. ${ }^{18}$ Therefore, the ECJ's interpretation of the fundamental rights in Community law will usually be parallel to that of a similar Convention right by the ECtHR. ${ }^{19}$ Arguably, the quality of the ECJ's case law regarding fundamental rights has profited to a great extent from this parallelism in interpretation. ${ }^{20}$ The ECtHR, too, increasingly refers to the ECJ's case law, which helps to create a uniform human rights standard in Europe. ${ }^{21}$

Parteien auf Stellungnahme zu den Schlussanträgen des Generalanwalts? Zur Vereinbarkeit des Verfahrens vor dem EuGH mit Art. 6 EMRK", Europarecht [2008] 345, 361-362; Sebastian Winkler, "Die Vermutung des ‘äquivalenten' Grundrechtsschutzes um Gemeinschaftsrecht nach dem Bosphorus-Urteil des EGMR", Europäische Grundrechte Zeitschrift [2007] 641, 643; a more cautious approach is adopted by: C. Eckes, "Does the European Court of Human Rights Provide Protection from the European Community? - The Case of Bosphorus Airways", 13 European Public Law (2007) 47, 54.

18) The first reference to the ECHR is contained in: Case 4/73 Nold KG $v$ Commission [1974] ECR 491, para. 12; the first reference to the ECtHR's case law can be found in: Case C-13/94 P $v S$ and Cornwall County Council [1996] ECR I-2143, para. 16; on (alleged) inconsistencies in the case law of the two courts cf. Dean Spielmann, "Human Rights Case Law in the Strasbourg and Luxembourg Courts: Conflicts, Inconsistencies and Complementarities" in P. Alston (ed.), The EU and Human Rights (OUP, Oxford 1999) p. 757; Nina Philippi, "Divergenzen im Grundrechtsschutz zwischen EuGH und EGMR", Zeitschrift für europarechtliche Studien [2000] 97. For the reasons why the ECJ relies on the ECtHR's case law cf. Guy Harpaz, "The European Court of Justice and its relations with the European Court of Human Rights: The quest for enhanced reliance, coherence and legitimacy", 46 Common Market Law Review [2009], 105, 109 seq. In addition, Harpaz argues for a "very strong albeit rebuttable presumption of deferral to the case law" of the ECtHR, ibid. at p. 115.

19) E.g. Case C-7/98 Krombach v Bamberski [2000] ECR I-1935; Case C-112/00 Schmidberger $v$ Austria [2003] ECR I-5659; Case C-60/00 Carpenter v Secretary of State for the Home Department [2002] ECR I-6279; cf. Anne Peters, Europäische Menschenrechtskonvention (C.H. Beck, München 2003) pp. 28-29; Hans Christian Krüger; Jörg Polakiewicz, "Proposals for a Coherent Human Rights Protection System in Europe", 22 Human Rights Law Journal (2001) 1, 6.

20) Cathryn Costello, "The Bosphorus Ruling of the European Court of Human Rights: Fundamental Rights and Blurred Boundaries in Europe", 6 Human Rights Law Review (2006) 87, 129. 21) E.g., in Pellegrin v France (App no 28541/95) ECHR 1999-VIII 207, para. 66 and Goodwin $v$ United Kingdom (App no 28957/95) ECHR 2002-VI. The ECtHR also helped to enforce Community law, e.g. Hornsby v Greece (App no 18357/91) ECHR 1997-II; S. A. Dangeville v France (App no 36677/97) ECHR 2002-III; cf. Dean Spielmann "La constitution économique de l'union européenne et les droits de l'homme" in O. Debarge et al. (eds.), La constitution 
This cooperation, however, is not based on a legal duty to cooperate, but merely on comity. That means that either court can unilaterally end this cooperation at any moment. ${ }^{22}$ This is one of the reasons why an accession of the European Community to the ECHR should be welcomed as an accession would provide for a clear legal basis for the relationship between Strasbourg and Luxembourg.

\section{The Future Part I: Entry into Force of the EU Charter of Funda- mental Rights}

But before an accession of the EU to the ECHR will take place, it is likely that the EU Charter of Fundamental Rights will enter into force. The European Parliament, the Council and the Commission solemnly proclaimed the EU Charter of Fundamental Rights at the Nice summit on 7 December $2000 .{ }^{23}$ As a consequence, the Charter is presently not binding. However, both the ECJ and the CFI increasingly refer to its provisions as a confirmation for their findings regarding the Community's fundamental rights. ${ }^{24}$ The reformed Article 6(1) TEU (Treaty of Lisbon) provides that the Charter of Fundamental Rights will have the same value as the Treaties. This means that the Charter will enter into force at the same time as the Treaty of Lisbon. Similarly, the failed European Constitution contained the Charter as its Part II. Even if the Treaty of Lisbon shares the fate of the Constitution, it is very likely that a new reform treaty will again provide for the Charter eventually entering into force. Thus it seems justified to explore the relationship between the Charter and the ECHR after the

économique de l'union européenne' (Bruylant, Bruxelles 2008) pp. 297, 311-316; Dean Spielmann, "La prise en compte et la promotion du droit communautaire par la Cour de Strasbourg", in Les droits de l'homme en evolution: Mélanges en l'honneur du professeur Petros J. Pararas (Bruylant, Brussels, 2009) pp. 455-472.

22) Nico Krisch, "The Open Architecture of European Human Rights Law", 71 Modern Law Review (2008) 183, 201.

23) $2000 \mathrm{OJ}$, C364/1; the amended version of the Charter to become binding according to the Lisbon Treaty can be found at: 2007 OJ, C303/1.

24) For instance: Case C-540/03 Parliament/Council [2006] ECR I-5769, para. 38; Case C305/05 Advocaaten van de Wereld v Leden van de Ministerraad [2007] ECR I-3633, para. 46; Case C-432/05 Unibet v Justitiekanslern [2007] ECR I-2271, para. 37; Case C-438/05 International Transport Workers' Federation and Finnish Seamen's Union v Viking Line ABP OÜ Viking Line Eesti [2007] ECR I-10779, para. 44; Case T-242/02 Sunrider v OHIM [2005] ECR II2793, para. 51. 
Charter has become binding, and its influence on the relationship between the two European courts.

\section{A. The ECHR as a Minimum Standard}

Article 52(3) of the Charter defines the relationship between the rights contained in the Charter and the ECHR:

In so far as this Charter contains rights which correspond to rights guaranteed by the Convention for the Protection of Human Rights and Fundamental Freedoms, the meaning and scope of those rights shall be the same as those laid down by the said Convention. This provision shall not prevent Union law providing more extensive protection.

This article aims to prevent that the human rights standard set by the Charter becomes lower than that of the ECHR. Article 52 of the Charter deals with the scope of the rights guaranteed. Therefore, a restriction of a fundamental right that is also guaranteed by the ECHR can only be justified if that restriction would also be permissible under the ECHR. Therefore, Article 52(3) provides for the ECHR as a minimum standard of human rights in the EU. Article 52(3) thus leads the EU to be indirectly bound by the ECHR as it must always be obeyed when restricting fundamental rights in the EU. The aim of Article 52(3) is to prevent Member States from being subjected to two different standards of human rights protection when implementing EU law. Therefore, Article 52(3) not only protects the status quo of the ECHR, but must also be read as a dynamic reference to the ECHR and its additional protocols. Should the ECHR be substantively amended in the future, these amendments will automatically become the new minimum standard of human rights protection in the EU. ${ }^{25}$

\footnotetext{
25) Kolja Naumann, "Art. 52 Abs. 3 GrCh zwischen Kohärenz des europäischen Grundrechtsschutzes und Autonomie des Unionsrechts", Europarecht [2008] 424, 426; Julia Molthagen Das Verhältnis der EU-Grundrechte zur EMRK, PhD thesis Hamburg, 2003, <http://www. sub.uni-hamburg.de/opus/volltexte/2003/967/>, 23 April 2009, at p. 89; Marc Fischbach, "Grundrechte-Charta und Menschenrechtskonvention" in W. Heusel (ed.), Grundrechtecharta und Ver-fassungsentwicklung in der EU (Bundesanzeiger-Verlag, Köln, 2002), 125, 126.
} 
A list of corresponding rights can be found in the official explanations relating to the Charter. ${ }^{26}$ According to Article 52(7) of the Charter, these explanations "shall be given due regard by the Courts of the Union and the Member States" when interpreting the Charter. Considering that Article 52(7) does not provide for the explanations to be binding but merely postulates a duty to duly regard them, it cannot be excluded that future case law will add other rights to that list.

\section{B. Does Article 52(3) Make ECtHR Case Law Binding?}

Having established that Article 52(3) of the Charter makes the ECHR the minimum standard when interpreting provisions of the Charter that correspond to those of the $\mathrm{ECHR}$, the question arises whether the interpreter of such provisions is also bound by the ECtHR's case law regarding those rights. The fact that only the ECtHR's (dynamic) interpretation shaped the rights contained in the ECHR and made the ECHR probably the most successful international human rights instrument, might suggest that that should be the case. Lenaerts and de Smijter contend that because the ECHR establishes the ECtHR and because the ECtHR interprets the rights laid down in the ECHR ex tunc it had to be assumed that the case law of the ECtHR formed an integral part of the meaning and scope of those rights. ${ }^{27}$ Considering that the ECJ will become the main interpreter of the Charter, such a result would lead to the ECJ being bound by the decisions of the ECtHR when interpreting the Charter. Regarding those rights, this would lead to a hierarchy of the two Courts with the ECtHR being at the top of that hierarchy.

\footnotetext{
26) Explanations relating to the Charter of Fundamental Rights, OJ 2007, C 302/33-34; that list, however, is not exhaustive: Yvonne Dorf, "Zur Interpretation der Grundrechtecharta”, Juristenzeitung [2005], 126, 129; Molthagen (n 25); Nina Philippi, Die Charta der Grundrechte der Europäischen Union (Nomos, Baden-Baden 2002), 44-45; Thomas von Danwitz, "Art 52 Grundrechtecharta" in P. J. Tettinger and K. Stern (eds.), Kölner Gemeinschaftskommentar zur Europäischen Grundrechte-Charta (C.H. Beck, München 2006) para. 55.

27) Koen Lenaerts and Eddy de Smijter, "The Charter and the Role of the European Courts", 8 Maastricht Journal of European Law (2001) 90, 99; a similar argument is put forward by Christian Busse, "Das Projekt der europäischen Grundrechtscharta vor dem Hintergrund der EMRK", Thüringisches Verwaltungsblatt [2001], 73, 79; similar but without giving reasons: Lord Goldsmith, "The Charter of Rights - a brake not an accelerator", European Human Rights Law Review [2004], 473, 476; Nikolaos Lavranos, "Das So-Lange-Prinzip im Verhältnis von EGMR und EuGH”, Europarecht [2006] 79, 80.
} 
When we look at the wording of Article 52(3), however, we cannot find any express reference to the ECtHR's case law. Only the ECHR itself is mentioned. The question is therefore, whether Article 52(3) can nonetheless be interpreted as containing such a reference. On the one hand, it is unlikely that the drafters of Article 52(3) wanted a mere reference to the 50 year old text of the ECHR, especially considering that the ECHR has for a long time been dynamically interpreted as a "living instrument" by the ECtHR and thus been rendered a great deal more precisely. ${ }^{28} \mathrm{On}$ the other hand, if one were to accept that the case law of the ECtHR will bind the interpreters of the Charter, this would mean that every further step in the development of human rights protection by the ECtHR would automatically become part of EU law. ${ }^{29}$

The official explanations regarding Article 52 (3) explicitly mention the case law. They state that " $[t]$ he meaning and scope of the guaranteed rights are determined not only by the text of those instruments, but also by the case law of the European Court of Human Rights and by the Court of Justice of the European Union". ${ }^{30}$ This certainly means that the case law of the ECtHR will be of great relevance when interpreting the corresponding rights in the EU-Charter. The preamble to the EU-Charter is phrased in a similar manner in that it also refers to the case law of the ECtHR and the ECJ. However, Article 52(7) only postulates a duty to duly regard these explanations and thus merely a duty to duly regard the ECtHR's case law. This does not imply that the interpreter of the EU-Charter must strictly follow that case law. Therefore, these explanations alone cannot provide a sufficient basis for the assumption that the ECJ would be bound by the ECtHR's case law.

However, a duty to follow the case law could follow from the object and purpose of Article 52(3), which aims at a parallel interpretation of both the

\footnotetext{
28) Naumann (n 25) p. 425; Johan Callewaert, "Die EMRK und die EU-Grundrechtecharta", Europäische Grundrechtezeitung [2003], 198, 199; Johan Callewaert, "Les rapports entre la Charte et la Convention européenne des droits de l'homme" in W. Heusel (ed.), Grundrechtecharta und Verfassungsentwicklung in der EU (Bundesanzeiger-Verlag, Köln, 2002) pp. 129, 132; Martin Borowsky, "Art. 52" in J. Meyer (ed.), Charta der Grundrechte der Europäischen Union (2nd edn., Nomos-Verlag, Baden-Baden. 2006) para. 37; Philippi (n 26), 45; Dorf (n 26), 128.

29) Borowsky (n 28) para. 37; Gerhard Ress, "Die Europäische Grundrechtscharta und das Verhältnis zwischen EGMR, EuGH und den nationalen Verfassungsgerichten" in A. Duschanek and S. Griller (eds.), Grundrechte für Europa (Springer, Vienna, 2002), 183, 206.

30) OJ 2007, C 302/33 [emphasis added].
} 
ECHR and the EU-Charter in order to avoid that the ECtHR might regard an act of EU law, which had previously been sanctioned by the ECJ, to infringe the ECHR. After all, the most effective way of avoiding such a situation would be a strict duty to follow the ECtHR's case law.

Yet such an explicit duty is nowhere to be found in the EU-Charter. Moreover, there had been various attempts to include an explicit reference to the ECtHR's case law during the Convention, which was responsible for drafting the Charter. ${ }^{31}$ Yet the Convention found it impossible to agree upon such a reference. ${ }^{32}$ Thus, both the wording and the drafting history of the Charter do not support a strict bindingness of the ECtHR's case law on the ECJ when interpreting the EU-Charter.

There is also a further, more general argument against the assumption that the ECtHR's case law should be binding on the ECJ: such a duty would be alien to European Union law. Court decisions under EU law are only binding inter partes. A duty to generally follow the case law of the ECtHR would implicate a great change in EU law, as it would basically introduce a doctrine of stare decisis as is typical for the common law. Were the ECJ to follow the case law of the ECtHR, the doctrine would go even further than normal as it would mean that a court of one legal order (the ECJ) would be bound by the decisions of a court of another legal order (the ECtHR). In addition, a doctrine of stare decisis only makes sense where there is a clear hierarchy of courts, including the possibility to file an appeal against decisions by the inferior court(s). An appeal gives the higher court an opportunity to review its own case law and adjust it. Therefore, it would be necessary to introduce a procedural means that would either enable a party to appeal to the ECtHR or that would allow the ECJ to make a preliminary reference to the ECtHR, in order to get guidance on the interpretation of the ECHR. That, however, is not the case. Moreover, the present right to file an individual complaint under Article 34 ECHR cannot be

31) CHARTE 4372/00 (CONVENT 39) containing proposals by the following members of the Convention: J. Meyer (p. 282); J.-P. Bonde (p. 487); J. Voggenhuber and K. Buitenweg (p. 560); D. Tarschys (p. 562); in addition, one of the observers of the Council of Europe argued in favour of such a reference: Marc Fischbach, "Le Conseil de l'Europe et la Charte des droits fondamentaux de l'union européenne", Revue Universelle des Droits de l'Homme [2000] 7, 8.

32) Regarding the discussions in the Convention: Jonas Bering Liisberg, "Does the EU Charter of Fundamental Rights Threaten the Supremacy of Community Law?", 38 Common Market Law Review (2001), 1171, 1172; Molthagen (n 25); Margit Bühler, Einschränkung von Grundrechten nach der Europäischen Grundrechtecharta (Duncker \& Humblodt, Berlin, 2005) pp. 320-321. 
regarded as a sufficient alternative to a formal appeal to the ECtHR for two reasons: Firstly, as long as the EU is not a party to the ECHR, such an individual complaint could only be directed against a Member State. Secondly, according to the Bosphorus presumption such a complaint would almost always be unsuccessful. It would not constitute a viable tool for an exchange between the two courts.

The foregoing arguments show that making the ECtHR's decisions binding on the ECJ would mean a paradigm shift in EU law. Had such a shift been wanted, an express provision would surely have been included in the EU Charter. Moreover, the ECtHR itself is not bound by its own decisions, nor does the ECHR provide that the national courts of the parties to the Convention be bound by its rulings. Article 46 ECHR only stipulates for a decision being binding inter partes.

Considering in addition that both the preamble and the explanations to Article 52(3) of the EU Charter mention the ECJ alongside the ECtHR suggests that neither Court is to be regarded superior to the other, but rather that both courts are regarded to co-exist as equals. ${ }^{33}$ For if one argues on that basis, that an interpreter of corresponding rights of the Charter and the ECHR should be bound by the case law of the ECtHR, one must also argue that such an interpreter is bound by the case law of the ECJ. Considering that the ECJ will be the final interpreter of the EU Charter, this would result in the ECJ being bound not only by the case law of the ECtHR, but also by its own case law. In a scenario where the case law of both courts is contradictory, the ECJ would thus be bound by both its own case law and that of the ECtHR. For the ECJ this would result in a conflict between the duty to follow the ECtHR's case law on the one hand, and the duty to follow its own case law on the other. This shows that in such a case the purpose of Article 52(3), which is to create coherence and consistency in European human rights law, would not be better served if there was no legal duty to follow either case law.

Moreover, the mentioning of the ECtHR's case law in the preamble of the EU Charter occurs in the context of the sources of the Charter rights and not in the context of the relationship between the EU Charter and the

33) Stefan Lorenzmeier, "Das Verhältnis von Europäischem Gerichtshof und Europäischem Gerichtshof für Menschenrechte - Konflikt oder Kooperation?" in J. Bast et al. (eds.), Die Europäische Verfassung - Verfassungen in Europa (Nomos, Baden-Baden 2005), 209, 223. 
ECHR. ${ }^{34}$ The preamble therefore suggests that the ECtHR's case law is merely one of several aids to interpreting the EU Charter. Therefore, it follows neither from Article 52(7) nor from the preamble that the case law of the ECtHR is binding. The explanations to Article 52 themselves confirm this result in that they stress that the autonomy of EU law and the ECJ must not be affected by Article 52(3). ${ }^{35}$

In conclusion, one cannot assume that once the EU Charter has entered into force, the ECJ will be bound by the case law of the ECtHR when interpreting rights that correspond to those of the ECHR.

\section{The Future Part II: Accession to the ECHR}

Under the Lisbon Treaty, the entry into force of the EU Charter of Fundamental Rights will not be the final step in the development of human rights in the EU. Article 6(2) of the new TEU provides that 'the Union shall accede to the European Convention for the Protection of Human Rights and Fundamental Freedoms. ${ }^{36}$ The inclusion of that provision was necessary as the ECJ decided in Opinion 2/94, that the European Community could not accede to the ECHR for lack of competence. ${ }^{37}$ Regarding the Convention, a new Article 59(2), introduced by Protocol 14 to the ECHR, will provide for a possibility of accession for the EU. ${ }^{38}$ Once the EU has become a party to the ECHR, further questions regarding the relationship between the two European courts will arise: First, the question of the exclusive jurisdiction of the ECJ to interpret agreements concluded by the EU; second, the question of the future of the Bosphorus presumption; and third, whether according to the obiter dictum in Opinion 1/91, the ECJ will be bound by the decisions of the ECtHR.

\footnotetext{
34) Molthagen (n 25) p. 126.

35) OJ 2007, C 302/33.

36) Art. I-9 of the failed European Constitution contained an identically worded provision.

37) Opinion 2/94 Accession to the ECHR [1996] ECR I-1759; this opinion had been requested following a long academic and political discussion; see e.g. Brid Moriarty, "EC Accession to the ECHR”, Hibernian Law Journal (2001) 13, 15.

38) Art. 17 of Protocol No. 14 to the ECHR, CETS No 194; that Protocol has so far been ratified by all members of the Council of Europe save Russia.
} 


\section{A. The Exclusive Jurisdiction of the ECJ after an Accession}

\section{The Exclusive Jurisdiction of the ECJ}

In order to accede to the $\mathrm{ECHR}$, the $\mathrm{EU}^{39}$ will conclude an agreement of accession according to the procedure laid down in Article 218(8) of the Treaty of the Functioning of the European Union. According to Article 216 (2) of that Treaty (the present Article 300(7) EC Treaty), the agreements concluded by the EU are binding on the EU and its Member States. Since its decision in the Haegeman case the ECJ has consistently held that the provisions of an agreement concluded by the Community form an integral part of Community law. ${ }^{40}$ An agreement of the Community can be regarded as an act of one of the institutions of the Community within the meaning of Article 234(1)(b) EC Treaty, so that the ECJ has jurisdiction to interpret it without there being a piece of Community legislation implementing the agreement in Community law.

In Haegeman, which dealt with the provisions of a mixed agreement, the ECJ did not yet draw a distinction between agreements concluded by the Community alone and mixed agreements. That distinction was made by the Court in Demirel, where the ECJ distinguished between those provisions of a mixed agreement that fell into the jurisdiction of the Community and those that fell into the exclusive jurisdiction of the Member States. ${ }^{41}$ Only in the latter case does the ECJ not have jurisdiction. ${ }^{42}$ This case law has since been confirmed. ${ }^{43}$

\footnotetext{
39) For the purpose of this Section, I will refer to the 'EU' as a future party considering that the 'Community' as a separate organization will cease to exist with the Treaty of Lisbon. For the readers' convenience I will refer to the provisions of the EC Treaty as they presently stand.

40) Case 181/73 Haegeman v Belgian State [1974] ECR 449, para. 5.

41) Case 12/86 Demirel v Stadt Schwäbisch Gmünd [1987] ECR 3719 para. 9; a detailed analysis of the ECJ's case law can be found in: Koutrakos (n 2) pp. 192-205.

42) Panos Koutrakos, "The Interpretation of Mixed Agreements under the Preliminary Reference Procedure" (2002) 7 European Foreign Affairs Review, 25, 30-34; Opinion of AG Tesauro, Case 53/96 Hermès International v FHT Marketing Choice [1998] ECR I-3606 para. 18; this interpretation of Demirel is criticized by Alan Dashwood, "Preliminary Rulings on the Interpretation of Mixed Agreements" in D. O'Keeffe and A. Bavasso (eds.), Judicial Review in European Law, Liber Amicorum in Honour of Lord Slynn of Hedley (Kluwer, The Hague. 2000) pp. 167, 170.

43) Case C-13/00 Commission/Ireland [2002] ECR I-2943 para. 14; Case C-239/03 Commission/France [2004] ECR I-9325 para. 25; Case C-459/03 Commission/Ireland [2006] ECR I4635, para. 84; cf. Erich Vranes, "Gemischte Abkommen und die Zuständigkeit des EuGH Grundfragen und neuere Entwicklungen in den Außenbeziehungen" [2009] EuR p. 44 at p. 59.
} 
It follows from Articles 220 and 292 EC Treaty that the jurisdiction of the ECJ to interpret such agreements is exclusive. Article 292 EC Treaty reads:

Member States undertake not to submit a dispute concerning the interpretation or application of this Treaty to any method of settlement other than those provided for therein. ${ }^{44}$

The object and purpose of that provision is to ensure that Community law is interpreted in a consistent manner, which can most efficiently be attained by making the Community courts the only courts deciding issues of Community law. The reference to 'this Treaty' in Article 292 EC Treaty not only refers to the EC Treaty as such, but also to secondary legislation. ${ }^{45}$ The exclusive jurisdiction of the ECJ was the reason why the ECJ in Opinion 1/91 held the draft agreement on the European Economic Area to be incompatible with the EC Treaty. ${ }^{46}$ That agreement provided for the establishment of an EEA Court, which was to decide about disputes between the 'contracting parties of the agreement', i.e. the EC, its Member States and the EFTA States. Depending on the case in question, a 'contracting party' could either mean the EC, a Member State or the EC and its Member States together depending on the distribution of competences under Community law. In case of a dispute, the EEA Court would have been forced to decide which party was internally competent under Community law, in order to decide who was to be regarded as the 'contracting party' for the dispute. ${ }^{47}$ The ECJ regarded that power conferred to the EEA Court to be incompatible with Community law as that power was exclusively vested in the ECJ according to Article 220 EC Treaty, a finding which was confirmed by Article 292 EC Treaty ${ }^{48}$ Opinion 1/91 shows that the exclusive jurisdiction of the ECJ to interpret Community law not only flows from

\footnotetext{
44) Art. 193 of the Euratom Treaty is worded in a similar manner.

45) Jonkheer H.F. van Panhuys, "Conflicts Between the Law of the European Communities and Other Rules of International Law", 3 Common Market Law Review (1965-1966) 420, 443; Bernhard Wegener, "Art. 292" in Christian Calliess and Matthias Ruffert (eds.), EUVIEGV (3rd edn. C.H. Beck, München 2007); Christoph Herrmann, "Art. 292" in R. Streinz (ed.), EUVI $E G V$ (C.H. Beck, München 2003).

46) Opinion 1/91 [1991] ECR I-6079.

47) Opinion 1/91 [1991] ECR I-6079 para. 34.

48) Opinion 1/91 [1991] ECR I-6079 para. 35.
} 
the express provision of Article 292 EC Treaty, but is inherent in the Community legal system.

However, the exclusive jurisdiction of the ECJ to interpret Community law does not end here. It also extends to the interpretation of agreements concluded by the Community. In the Mox Plant case, for instance, a mixed agreement, the United Nations Convention on the Law of the Sea (UNCLOS) was at issue. Here the Commission alleged that Ireland had breached the EC Treaty by submitting a dispute with the United Kingdom to the dispute settlement mechanism under UNCLOS. $4^{4}$ UNCLOS had been concluded by the Community as a mixed agreement. The ECJ held that Ireland had in fact breached its obligations under the EC Treaty by submitting a dispute regarding provisions of the UNCLOS to a forum other than the ECJ, as the Community had exercised its competence regarding the provisions in question. ${ }^{50}$ Therefore, these provisions had to be regarded as an integral part of Community law for the interpretation of which the ECJ had exclusive jurisdiction.

Regarding the ECHR, the question is whether the ECJ will also claim to be (solely) competent to interpret its provisions as far as Community law is concerned. The ECHR will be acceded to by the EU alone because the Member States are already parties to it. Nonetheless, it will have to be qualified as a mixed agreement, as both the EU and the Member States will be parties to it. According to the ECJ's Haegeman case law, the ECHR will thus become an integral part of EU law and the ECJ will have exclusive jurisdiction to interpret it. The question of course is whether that will generally be the case or only in certain circumstances. The difference to a

\footnotetext{
49) Case C-459/03 Commission v Ireland [2006] ECR I-4635.

50) Case C-459/03 Commission v Ireland [2006] ECR I-4635, paras. 83-139; for detailed analyses of that judgment see: Nikolaos Lavranos, "The MOX Plant Judgment of the ECJ: How Exclusive is the Jurisdiction of the ECJ?", European Environmental Law Review (2006) 291; Nikolaos Lavranos, "The MOX Plant and Ijzeren Rijn Disputes: Which Court Is the Supreme Arbiter?" 19 Leiden Journal of International Law (2006) 223; Nikolaos Lavranos, "Protecting its Exclusive Jurisdiction: The Mox Plant-Judgment of the ECJ", 5 Law and Practice of International Courts and Tribunals (2006) 479; Nikolaos Lavranos, "The scope of the exclusive jurisdiction of the Court of Justice", 32 E.L.Rev. (2007) 83; Cesare P. Romano, 101 American Journal of International Law (2007) 171; Bernhard Wegener, "Familienstreitigkeiten nicht nach außen tragen?!", Zeitschrift für Umweltrecht [2006] 582; Karen Kaiser, "Ausschließliche Zuständigkeit des EuGH bei Auslegung und Anwendung von zum Gemeinschaftsrecht gehörenden Bestimmungen", Europäische Zeitschrift für Wirtschaftsrecht [2006] 464; Raphael Oen, "Streitschlichtung zwischen EG-Mitgliedstaaten im Rahmen gemischter Verträge”, 45 Archiv des Völkerrechts (2007) 136.
} 
'normal' mixed agreement will be that the reason for a membership of both the EU and its Member States differs from the normal situation, where neither could alone be a member of the whole agreement due to a division of competences between the EU and its Member States. That would not be the case here as the EU does not have the competence regarding certain human rights while the Member States are competent regarding certain other human rights. Therefore the decisive factor for the ECJ's jurisdiction regarding the ECHR cannot be whether the relevant provision of the ECHR falls in the exclusive jurisdiction of the Member States. It is rather suggested that only if EU law was applicable in the case at question, the ECJ will have jurisdiction to interpret it. This means that the ECJ will not be able to claim jurisdiction in cases concerning wholly internal situations such as criminal law. ${ }^{51}$

\section{The Conflict with the ECtHR's Exclusive Jurisdiction}

The ECJ's jurisprudence on its own exclusive jurisdiction to interpret agreements concluded by the EU, might, however, clash with the ECtHR's exclusive jurisdiction in inter-state disputes according to Article 55 ECHR. Article 55 ECHR reads:

The High Contracting Parties agree that, except by special agreement, they will not avail themselves of treaties, conventions or declarations in force between them for the purpose of submitting, by way of petition, a dispute arising out of the interpretation or application of this Convention to a means of settlement other than those provided for in this Convention.

This provision leads to an exclusive jurisdiction of the ECtHR over disputes between the parties to the Convention under Article 33 ECHR. After the EU has acceded to the ECHR, cases between its Member States or between the EU and a Member State could potentially be adjudicated by the ECJ (Articles 226 and 227 EC Treaty) and the ECtHR. Considering that both courts would regard their jurisdiction as exclusive, one must

\footnotetext{
51) In contrast to this, A.G. Toth, "The European Union and Human Rights: The Way Forward", 34 Common Market Law Review (1997) 491, 509, argues that the ECJ would have jurisdiction over any provision of the ECHR irrespective of whether the matter falls within the competence of the EC or the Member States.
} 
ask which court would be competent to adjudicate such cases. A conflict of jurisdiction could thus arise.

In contrast to that of the ECJ, the exclusive competence of the ECtHR is not an absolute one as it allows for special agreements between the parties to the Convention regarding their disputes. One possibility to solve this jurisdictional conflict would be to regard Articles 220 and $292 \mathrm{EC}$ as a 'special agreement' between the Member States and the EU. The question is, however, whether it is possible to regard these articles as such an agreement. Firstly, it could be argued that Article 55 ECHR requires that the special agreement be concluded between all the parties to the Convention. And secondly, one could contend that Article 55 ECHR demands that the special agreement must specifically refer to the ECHR. Neither condition would be fulfilled by Articles 220 and 292 EC as the EC Treaty is an agreement only between some of the parties to the Convention and it is phrased in a general manner.

\section{a. Agreement Only between the EU and its Member States}

Addressing the first issue whether an agreement only between the EU and its Member States is sufficient to satisfy Article 55 ECHR, one first has to concede that the wording of Article $55 \mathrm{ECHR}$ is not clear in this respect. ${ }^{52}$ The ECommHR argued that it was enough to satisfy the requirements of ex Article $62 \mathrm{ECHR}$, which was phrased in exactly the same manner as Article 55 ECHR, if both parties to the dispute have agreed upon another procedure than that before the ECommHR..$^{53}$ The ECommHR's interpretation in this decision is supported by the travaux préparatoires. The Swedish proposal regarding that article expressly stated that 'the parties concerned' could decide to submit the dispute in question to another forum. ${ }^{54}$ That

52) Some commentators contend that the agreement has to be concluded between all the parties to the ECHR: Joachim A. Frowein and Wolfgang Peukert, EMRK-Kommentar Art. 62 (2nd edn., N.P. Engel Verlag, Kehl, 1996); Wilhelm H. Wilting, Vertragskonkurrenz im Völkerrecht (Carl Heymanns Verlag, Köln, 1996) p. 223.

53) Cyprus v Turkey (App No 25781/94) ECommHR 28 June 1996.

54) Collected Edition of the "Travaux Préparatoires" of the European Convention on Human Rights, Volume 5 (Martinus Nijhoff Publishers, The Hague, 1979) p. 58; the proposal was phrased: "The Commission and the European Court having been created to settle disputes relating to the interpretation and the application of this Convention, such disputes shall not be submitted to other judicial or arbitral tribunals established by treaties or declarations in force unless the Parties concerned shall so decide by an agreement expressly relating to the dispute in question". 
proposal was not rejected during the drafting process of the ECHR. Only the wording was slightly changed so that one can infer that the drafters did not want to substantially change the Swedish proposal. Such an interpretation is supported by the nature of the ECHR compared to that of the EU. The latter is an autonomous legal order, which avails itself of a Court of Justice with an exclusive jurisdiction, in order to ensure a coherent interpretation of EU law. In contrast to that, the ECHR cannot be regarded as an autonomous legal order, as it aims at protecting universal human rights. Therefore the exclusive jurisdiction given to the ECtHR by Article 55 ECHR does not seem to serve the purpose of protecting the ECHR from being interpreted by another forum as was argued by Shany. ${ }^{55}$ Rather it was the aim of Article 55 ECHR to prevent parties to the Convention from being subjected to international adjudication against their will. This can only be understood before the background of the original version of the ECHR. The original legal situation was comparable to that before the ICJ, in that the parties had to agree to the jurisdiction of the ECtHR. ${ }^{56}$ Therefore, Article $55 \mathrm{ECHR}$ was mainly designed to prevent that a party to the Convention would be forced to respond to a dispute concerning the ECHR before another court, if that other court could claim jurisdiction over disputes between the parties. Thus, there is neither any evidence from the drafting process, nor from the object and purpose of Article $55 \mathrm{ECHR}$, that the special agreement under Article 55 ECHR would have to be concluded between all the parties to the ECHR. It follows that a special agreement between some of the parties to the ECHR suffices.

\section{b. Specific Reference to ECHR in the Special Agreement}

The second question is whether a 'special agreement' pursuant to Article 55 ECHR has to refer specifically to the ECHR or whether it is sufficient if that agreement simply confers jurisdiction over a certain type of dispute over Convention rights, e.g. where both parties to a dispute before the ICJ generally accepted its jurisdiction in accordance with Article 36(2) of the ICJ Statute. Only if that were the case, would Articles 220, 292 EC Treaty qualify as such a special agreement. The intention of the drafters of the ECHR was to avoid that parties to the Convention would be subjected to court proceedings on the basis of general jurisdiction clauses. Article 55

\footnotetext{
55) Shany (n 1), 191.

56) Ex Art. 48 ECHR.
} 
ECHR (ex Article 62) was especially aimed at declarations according to Article 36(2) of the ICJ Statute, with which a State can declare that it generally accepts the jurisdiction of the ICJ. In such a case, Article 55 ECHR was supposed to prevent such a dispute, by prescribing the exclusive jurisdiction of the ECtHR. Therefore the drafting history suggests that a general clause such as Articles 220, 292 EC would not be sufficient.

However, it seems that the original idea behind Article 55 ECHR is no longer applicable as the jurisdiction of the ECtHR has become obligatory after Protocol 11 entered into force on 1 November 1998. Therefore, parties to the Convention no longer need to be protected from being subjected to court proceedings alleging an infringement of the ECHR as they now must answer these cases in any event. Nonetheless, Article 55 (ex Article 62) ECHR remained part of the Convention. Therefore one may wonder which function that provision now has, as the parties to the Convention can no longer escape their responsibilities thereunder. It is unlikely that the drafters of Protocol 11 merely overlooked Article 55 and forgot to remove it from the Convention, because they changed its numbering. Thus one can conclude that Article $55 \mathrm{ECHR}$ has a function that differs from that of ex Article 62 ECHR. Being an exclusive jurisdiction clause, the function of Article 55 ECHR can now only be generally to exclude other courts and tribunals from deciding cases based on the ECHR, in order to ensure its consistent interpretation by the ECtHR. Considering that the ECtHR is the only court deciding on (the far more frequent) applications by individuals according to Article $34 \mathrm{ECHR}$, it makes sense to confer a similar exclusivity to the ECtHR regarding inter-state cases. The question then is why does Article $55 \mathrm{ECHR}$ still provide for a possibility to present the dispute to another forum. That can be explained by the fact that the ECHR, in contrast to the EU, is not an autonomous and self-contained legal order. ${ }^{57}$ Therefore, the parties should be given the opportunity to have the dispute decided by another forum if they expressly wish to do so. Thus, Article 55 ECHR creates a default rule that the ECtHR is competent to adjudicate inter-state disputes. Bearing in mind that exceptions to the rule must be construed narrowly, an agreement transferring jurisdiction to another forum will have to relate specifically to the ECHR. Therefore, the general exclusive competence of the ECJ according to Articles 220 and

57) The ECJ recently confirmed that autonomy in its Kadi judgment, cf. Joined Cases 402/05 P and 415/05 P Kadi and al Barakaatv Council, Judgment of 3 September 2008, [2008] ECR I-6351. 
292 EC Treaty does not satisfy the requirements of Article 55 ECHR. Thus both the ECJ and ECHR will be competent to adjudicate such inter-state disputes. Therefore, a conflict of jurisdictions arises.

In order to solve that conflict, the EU and its Member States would have to conclude a special agreement explicitly referring to the ECHR stating that the Convention will be interpreted by the ECJ in cases between the Member States or between a Member State and the EU. ${ }^{58}$ Such an agreement will preserve the exclusive jurisdiction of the ECJ and will at the same time be in accordance with the requirements of the ECHR.

\section{B. The New Relationship between the ECJ and the ECtHR}

\section{The Future of the Bosphorus Presumption}

As already mentioned, the present relationship between the ECJ and the ECtHR is characterized by a mutual exercise of comity in that both courts respect the work of the other. In Bosphorus, the ECtHR showed a great degree of deference towards the ECJ, in that it is presumed that the human rights protection under Community law is equivalent to that required by the ECHR. However, it is doubtful whether that presumption will still be justifiable after an accession. An accession of the EU to the ECHR will provide a solid legal basis for a review of alleged human rights violations committed by the organs of the EU. That review will also include decisions of the ECJ. As previously mentioned, the Bosphorus presumption should be applied in cases where only the Community acted. It would hardly be justifiable if that presumption were to be retained in such cases, because it would deprive the ECtHR of a great deal of cases arising within the EU. It would moreover lead to an unequal treatment of the different parties to the ECHR, in that the presumption would privilege the EU. ${ }^{59}$

\footnotetext{
58) Others have argued that it would become necessary to make a reservation (Art. 57 ECHR) or even to completely exclude the possibility of an inter-state dispute for all Member States and the EU: European Commission, Memorandum on the accession of the European Communities to the Convention for the Protection of Human Rights and Fundamental Freedoms, Bulletin of the European Commission, Supplement 2/79, para. 27; pleadings by the Spanish government regarding Opinion 2/94 Accession to the ECHR [1996] ECR I-1759; Molthagen (n 25) p. 195; Gerhard Baumgartner, "EMKR und Gemeinschaftsrecht", Zeitschrift für Verwaltung [1996], 319, 330; Steering Committee on Human Rights, CDDH(2002)010 Addendum 2, para. 63.

59) Even regarding the present relationship between the two courts an alleged double-standard has been criticized, cf. the joint concurring opinion by Judges Rozakis, Tulkens, Traja, Botoucharova, Zagrebelsky and Garlicki in the Bosphorus case, para. 4; Eckes (n 17), 65.
} 
Considering that the ECtHR does not grant such a privilege to any of the highest national courts of the parties to the ECHR, such a privilege for the ECJ is hardly justifiable. ${ }^{60}$ This argument is reinforced by the fact that such a privilege is even denied to those national courts that provide for a more effective protection of human rights than the ECJ, e.g. by granting easier access. In addition, after an accession to the ECHR, the need for the ECtHR to exercise comity will have ended. The justification for the exercise of comity was that the relationship between the two European courts is presently not fully clear. After an accession that will no longer be the case. Therefore, it is to be expected that the ECtHR will give up its Bosphorus jurisprudence after an accession. ${ }^{61}$

2. Binding Effect of ECtHR Decisions on the ECJ According to Opinion 1/91? A further question is whether an accession by the EU to the ECHR could lead the ECJ to apply its famous dictum in Opinion 1/91 for the first time, thus making the ECtHR's case law binding for the ECJ. It reads:

Where, however, an international agreement provides for its own system of courts, including a court with jurisdiction to settle disputes between the Contracting Parties to the agreement, and, as a result to interpret its provisions, the decisions of that court will be binding on the Community institutions, including the Court of Justice. Those decisions will also be binding in the event that the Court of Justice is called upon to rule, by way of preliminary ruling or in a direct action, on the interpretation of the international agreement, in so far as that agreement is an integral part of the Community legal order. ${ }^{62}$

\footnotetext{
60) After an accession, the proceedings before the ECJ will no longer be regarded as "another procedure of international investigation or settlement" according to Art. 35 ECHR as the ECJ will have to be treated like any highest court of a party to the Convention: Steering Committee for Human Rights CDDH (2002)010 Addendum 2, para. 48-49; Leo Zwaak in P. Van Dijk et al. (eds.), Theory and Practice of the European Convention on Human Rights (4th edn., Intersentia, Antwerp 2006), 183.

61) Laurent Scheeck, "The Relationship between the European Courts and Integration through Human Rights", 65 Zeitschrift für ausländisches öffentliches Recht und Völkerrecht (2005), 837, 862; Douglas-Scott (n 10), 243, 252; Andreas Haratsch, "Die Solange-Rechtsprechung des Europäischen Gerichtshofs für Menschenrechte", 66 Zeitschrift für ausländisches öffentliches Recht und Völkerrecht (2006) 927, 945.

62) Opinion 1/91 [1991] ECR I-6079 para. 39.
} 
As the ECHR constitutes an international agreement with its own court, the dictum seems to be applicable. The rationale behind the binding effect of these decisions on the organs of the Community, which includes the $\mathrm{ECJ}$, is that the EU as a party to an agreement, is bound by that agreement. If that agreement provides that the parties to it are bound by the decisions of the Court established to interpret the agreement, the EU, and therefore its organs (including the ECJ), are bound by these decisions. It is, however, not clear from the above quote how far that binding effect of decisions goes. It is rather unlikely that the ECJ intended to introduce a doctrine of stare decisis through the back door as such a doctrine does not exist anywhere in Community or international law. Moreover, under international law only the decisions rendered in proceedings to which the EU was a party are binding on it. Considering the rationale behind the dictum in Opinion 1/91 is to be found in international law, the ECJ is only bound by an interpretation of an international agreement rendered in cases where the EU was a party to the proceedings. Regarding the ECHR, this is evidenced by Article 46 ECHR, which shows that the decisions of the ECtHR are only binding inter partes. Therefore, the ECJ is only bound by those decisions to which the EU was a party. It follows that where the ECtHR finds that the EU has violated the rights guaranteed in the ECHR, the ECJ will be bound by that decision when interpreting provisions of the ECHR in a subsequent case dealing with the same issue. Such a situation might, for example, arise where the applicant has suffered a damage due to the EU's human rights violation and then sues the EU according to the present Article 288(2) EC Treaty. ${ }^{63}$ The ECJ will in such a case be required to decide whether there has been a violation of the ECHR. Where the applicant has already obtained a judgment by the ECtHR finding an infringement of the ECHR regarding the same matter, the ECJ is bound to follow that judgment.

63) Regarding the decisions of the WTO Dispute Settlement Body, the ECJ has been unwilling to recognize them as binding, mainly due to the peculiarities of WTO law: Case C-377/02 Van Parys v BIRB [2005] ECR I-1465; Confirmed in: Case 351/04 Ikea Wholesale Ltd. v Commissioner of Customs \& Excise [2007] ECR I-7723. 


\section{Conclusion}

The relationship between the two European courts is likely to undergo significant changes in the future. Presently, the ECtHR puts the ECJ in a privileged position as the ECtHR will generally presume that the ECHR was not violated in cases where there was a possibility of judicial review by the ECJ and where the Member State held responsible for an alleged violation of the ECHR did not have discretion in implementing Community law. This approach is justified by the fact that the ECJ usually follows the ECtHR's interpretation of the ECHR and thereby helps to maintain a relatively high human standard in the European Community. This situation will not significantly change once the EU Charter of Fundamental Rights has entered into force. The ECHR will remain the minimum human rights standard in the EU. The ECJ will be bound to interpret the ECHR but will not be bound to follow the ECtHR's case law. It can, however, be expected that the cooperation between the two European courts will increase somewhat further. After the EU's accession to the ECHR, the present coexistence of the two European courts will change. The ECJ's decisions will become directly reviewable by the ECtHR. In addition, the reason for the Bosphorus jurisprudence, which puts the ECJ in a privileged position relative to national courts, will disappear and that jurisprudence will probably be given up. Moreover, the ECJ will be bound to follow the ECtHR's decisions, where the EU was a party to previous proceedings in the same matter. 
Copyright of Law \& Practice of International Courts \& Tribunals is the property of Martinus Nijhoff and its content may not be copied or emailed to multiple sites or posted to a listserv without the copyright holder's express written permission. However, users may print, download, or email articles for individual use. 